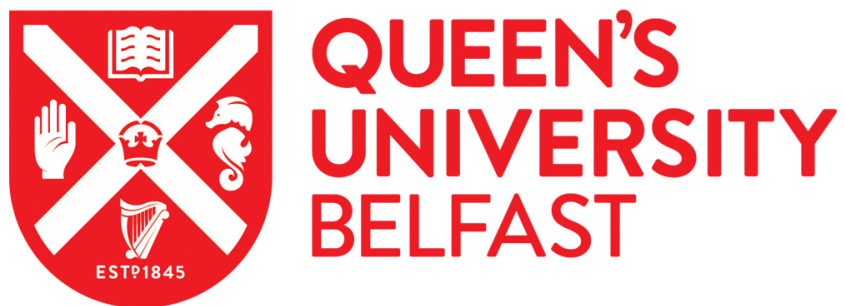

\section{Effects of 20mph interventions on a range of public health outcomes: A meta-narrative evidence synthesis}

Cleland, C. L., McComb, K., Kee, F., Jepson, R., Kelly, M., Milton, K., Nightingale, G., Kelly, P., Baker, G., Craig, N., Williams, A., \& Hunter, R. F. (2019). Effects of $20 \mathrm{mph}$ interventions on a range of public health outcomes: A meta-narrative evidence synthesis. Journal of Transport and Health. https://doi.org/10.1016/j.jth.2019.100633

Published in:

Journal of Transport and Health

Document Version:

Peer reviewed version

Queen's University Belfast - Research Portal:

Link to publication record in Queen's University Belfast Research Portal

Publisher rights

Copyright 2019 Elsevier

This manuscript is distributed under a Creative Commons Attribution-NonCommercial-NoDerivs License

(https://creativecommons.org/licenses/by-nc-nd/4.0/), which permits distribution and reproduction for non-commercial purposes, provided the author and source are cited.

\section{General rights}

Copyright for the publications made accessible via the Queen's University Belfast Research Portal is retained by the author(s) and / or other copyright owners and it is a condition of accessing these publications that users recognise and abide by the legal requirements associated with these rights.

Take down policy

The Research Portal is Queen's institutional repository that provides access to Queen's research output. Every effort has been made to ensure that content in the Research Portal does not infringe any person's rights, or applicable UK laws. If you discover content in the Research Portal that you believe breaches copyright or violates any law, please contact openaccess@qub.ac.uk. 
TITLE: Effects of $20 \mathrm{mph}$ interventions on a range of public health outcomes using the meta-narrative method

AUTHORS: Claire L Cleland ${ }^{1}$, Katy McComb ${ }^{1}$, Frank Kee ${ }^{1}$, Ruth Jepson ${ }^{2}$, Mike Kelly $^{3}$, Karen Milton ${ }^{4}$, Glenna Nightingale ${ }^{5}$, Paul Kelly ${ }^{6}$, Graham Baker ${ }^{6}$, Neil Craig ${ }^{7}$, Andrew Williams ${ }^{8}$, Ruth F Hunter ${ }^{1 *}$.

${ }^{1}$ UKCRC Centre of Excellence for Public Health (NI)/Centre for Public Health, Queen's University Belfast, Belfast, United Kingdom.

${ }^{2}$ The Scottish Collaboration for Public Health Research (SCPHRP), School of Health in Social Science, University of Edinburgh, Edinburgh, United Kingdom.

${ }^{3}$ Institute of Public Health, University of Cambridge, Cambridge, United Kingdom.

${ }^{4}$ Norwich Medical School, University of East Anglia, Norwich, United Kingdom.

${ }^{5}$ Centre for Population Health Sciences, Usher Institute of Population Health Sciences and Informatics, University of Edinburgh, Edinburgh, United Kingdom.

${ }^{6}$ Institute for Sport, Physical Education and Health Sciences, University of Edinburgh, Edinburgh, United Kingdom.

${ }^{7}$ Department of Public Health Sciences, NHS Scotland, Edinburgh, United Kingdom.

${ }^{8}$ College of Medicine and Health, University of Exeter, Exeter, United Kingdom.

Author email addresses: c.cleland@qub.ac.uk, kmccomb08@qub.ac.uk, f.kee@qub.ac.uk, ruth.jepson@ed.ac.uk, mk744@medschl.cam.ac.uk, K.Milton@uea.ac.uk, Glenna.Nightingale@ed.ac.uk, p.kelly@ed.ac.uk, graham.baker@ed.ac.uk, neil.craig@nhs.net, A.Williams2@exeter.ac.uk, ruth.hunter@qub.ac.uk

\section{*Corresponding author information:}

Dr Ruth Hunter, UKCRC Centre of Excellence for Public Health (Northern Ireland)/Centre for Public Health, School of Medicine, Dentistry and Biomedical Sciences, Queen's University Belfast, Belfast, UK, BT12 6BJ; E-mail: ruth.hunter@qub.ac.uk 


\section{HIGHLIGHTS}

1. 20mph zones appear to be effective in reducing the number and severity of collisions and casualties.

2. Insufficient evidence for $20 \mathrm{mph}$ limits and the reduction of number and severity of collisions/casualties.

3. Insufficient evidence on the impact of $20 \mathrm{mph}$ zones and speed limits for liveability and pollution.

4. $20 \mathrm{mph}$ zones appear more effective compared to $20 \mathrm{mph}$ limits; however, limits require more research.

5. Transparent reporting is required to determine the most in/effective components of $20 \mathrm{mph}$ zones and limits. 


\section{ABSTRACT}

\section{Background}

Road traffic injuries are a leading cause of preventable death globally, but can be reduced by introducing speed lowering interventions such as $20 \mathrm{mph}$ or $30 \mathrm{~km} / \mathrm{h}$ speed 'zones' and 'limits'. 'Zones' utilise physical traffic calming measures and 'limits' only utilise signage and lines. Transport is a social determinant of health and therefore such interventions may in/directly also impact on other health outcomes.

\section{Aim}

To investigate the effect of $20 \mathrm{mph}$ speed 'zones' and 'limits' on a range of health outcomes, and to establish if there are differences in the effectiveness of $20 \mathrm{mph}$ zones and $20 \mathrm{mph}$ limits.

\section{Methods}

MEDLINE, EMBASE, Web of Science and Transport Research Information Service (TRIS) databases were searched [1983-January 2019) to identify relevant studies. Reference lists, relevant systematic reviews and the grey literature were also searched. Inclusion criteria: 20 mph 'zone' or 'limit' interventions: and public health outcomes (collisions, casualties, mode of transport, noise pollution, air quality, inequalities and liveability (e.g. physical activity and perceptions of safety)) and including a control/comparison group.

\section{Results}

Eleven studies were identified reporting nine $20 \mathrm{mph}$ 'zone' and two $20 \mathrm{mph}$ 'limit' interventions. 20 mph 'zones' were associated with a reduction in the number and severity of collisions and casualties; have less robust evidence of the effect on air pollution; and have the potential to indirectly impact physical activity and liveability through various mechanisms for change (although currently the evidence is lacking and requires further work). No significant associations were reported between 20 mph 'limits' and any public health outcome.

\section{Conclusion}


This review suggests $20 \mathrm{mph}$ 'zones' are effective in reducing collisions and casualties. However, it provides insufficient evidence to draw conclusions on the effect of $20 \mathrm{mph}$ 'zones' on pollution, inequalities or liveability. For $20 \mathrm{mph}$ 'limits' more rigorous evaluations are required in order to draw robust conclusions.

\section{KEYWORDS}

$20 \mathrm{mph}$, speed limits, speed zones, public health, transport, meta-narrative review. 


\section{INTRODUCTION}

Previously published literature has made the case for transport as a social determinant of health and as a major factor influencing health inequalities (Marmot and Bell, 2012; Braveman et al., 2011; The Health Foundation, 2018). The impacts of transport are multi-faceted affecting health both directly and indirectly with collisions (i.e. an "incident" involving a person and at least one road vehicle) and casualties (i.e. a casualty is when a person/s is killed or injured during a collision) (WHO, 2009; Jackson and Cracknell, 2018) having the most detrimental effects.

Worldwide, across all age groups, casualties and collisions have been estimated to be the $10^{\text {th }}$ leading cause of death, with the most vulnerable populations (i.e. pedestrians, cyclists, and motorcyclists) representing almost half of global fatalities (WHO, 2009; WHO, 2015; Jackson and Cracknell, 2018).

In addition to the apparent risk that transport poses to health through the number and severity of collisions and casualties, transport can also impact other health outcomes and health behaviours such as physical activity, sedentary behaviour, walking and cycling behaviour, liveability, pollution (both air and noise). Regarding physical activity and sedentary behaviour it has been widely acknowledged that both are major risk factors for morbidity and mortality, with walking and cycling being suggested as practical ways of meeting physical activity guidelines and reducing sedentary behaviour (Heath et al., 2006; Yang et al., 2010). However, both walking and cycling have been found to potentially be impeded by transport and transport networks as individuals may be, or perceive to be, unsafe when walking and/or cycling in their neighbourhoods forcing them to travel by motorised transport potentially reducing physical activity levels and increasing sedentary behaviour (Heath et al., 2006; Yang et al., 2010). Previous research has also shown that liveability can be negatively affected by motorised transport, as those living on streets with a high traffic volume were found to have a significantly lower number of friends and acquaintances which can result in increased feelings of social isolation and loneliness, and ultimately an increased likelihood of all-cause mortality (Hart and Parkhurst, 2011; Holt-Lunstad et al., 2015). Furthermore, transport has been established as a major 
source of air pollutants, exposure to which, has been linked to obesity, asthma, cardiovascular disease and cancer (Department for Environment Food and Rural Affairs, 2018; Royal College of Physicians and the Royal College of Paediatrics and Child Health, 2016). Air pollution affects everyone, although the impact is heightened by living and/or working near busy roads or deprived areas and pre-existing medical conditions (Department for Environment Food and Rural Affairs, 2018; Royal College of Physicians and the Royal College of Paediatrics and Child Health, 2016. In addition, noise pollution can also be harmful to both physical and mental health, with road transport being a leading source of environmental noise (Khreis et al., 2017). Such health impacts, also result in a source of considerable economic burden. In the UK, physical inactivity and air pollution are estimated to cost $£ 1.5$ and $£ 20$ billion respectively per year, when health and social care, employment absence and other factors are accounted for (Royal College of Physicians and the Royal College of Paediatrics and Child Health, 2016; British Heart Foundation, 2017). Consequently, calls have been made for modifications to the built environment and transport networks to alleviate the burden on health by implementing and/or improving: speed calming measures (speed limit signage, speed bumps, chicanes), cycle lanes, footpaths, pedestrian crossings etc. in order to improve health both directly and indirectly and to produce economic benefits (Sallis et al., 2009; Panter et al., 2016).

A common transport intervention is $20 \mathrm{mph}$ speed restrictions which aim to not only reduce speed but also to improve road safety and the perception of road safety, and to reduce the number and severity of collisions and casualties. Research has shown that when drivers exceed the speed limit this causes $5 \%$ of all collisions and $15 \%$ of fatal crashes; and when pedestrians are hit by a car they have a gradually increasing risk of being killed at impact speeds up to $30 \mathrm{mph}$. However, between $30-40 \mathrm{mph}$ this risk of fatality increases rapidly (3.5-5.5 times) (Department for Transport, 2017; Richards, 2010). Injuries to cyclists show a similar pattern with increased probability of fatality with higher vehicle speed. In high speed environments the risk of collisions for children and the elderly also increase due, respectively, to their underdeveloped and declining motion perception abilities and their inability to accurately judge speed and available crossing time (Wann et al., 2011; Lobjois and Cavallo, 2007; 
Webb et al., 2017). Speed restrictions also have the potential to increase physical activity primarily through the encouragement of walking and cycling behaviour, reduce sedentary behaviour and improve the liveability of an area. Further, spill over effects in adjacent and non-adjacent zones can occur due to the connected and interdependent components of transport and health. Slower speeds can provide individuals with improved perception of road safety in turn, encouraging active travel to work and school, recreational walking and cycling, and outdoor play (20's Plenty for Us, 2015). $20 \mathrm{mph}$ speed restrictions have also been reported to have the potential to reduce fuel consumption, and decrease air pollution, as standing traffic is reduced, allowing more efficient use of the available road space and more effective merging and filtering at junctions, reducing traffic queues (20's Plenty for Us, 2012; 20's Plenty for Us, 2010; Jones and Brunt, 2017). Therefore, $20 \mathrm{mph}$ speed restrictions may have other public health impacts beyond road safety measures and the evaluation of their effectiveness as a public health intervention on a range of health outcomes is warranted.

Currently there are two main intervention approaches to implement $20 \mathrm{mph}$ speed restrictions in urban areas. 20 mph 'zones' involve physical traffic calming measures such as road narrowing, speed bumps, central islands and chicanes which are designed to slow vehicle speed and to ensure that the $20 \mathrm{mph}$ speed limit is adhered to. These traffic calming measures can be used individually or in combination, therefore 20 mph 'zones' can differ between areas (Department for Transport, 2007). In contrast, $20 \mathrm{mph}$ 'limits' involve only signage and/or lines which are used to alert drivers to the speed limit and do not involve physical infrastructure to decrease speed. The $20 \mathrm{mph}$ speed restrictions are legally enforceable and may also be supported by awareness and education campaigns (Toy et al., 2014).

An umbrella review published in 2015 investigated the effect of $20 \mathrm{mph}$ interventions on health and health inequalities (Cairns et al., 2015). However, this review did not distinguish between the impact of $20 \mathrm{mph}$ 'zones' and $20 \mathrm{mph}$ 'limits', and limited the outcomes to crashes, collisions, injuries, traffic speed and volume (Cairns et al., 2015). In addition, no evidence was presented for the impacts on 
socio-economic inequalities and the subsequent outcome/s (Cairns et al., 2015). For that reason, the authors concluded that "further controlled evaluations that specifically examine socio-economic effects" were required (Cairns et al., 2015). In addition, despite the rise in 20 mph speed restriction interventions, no review to date has investigated the distinct impact of $20 \mathrm{mph}$ 'zones' and $20 \mathrm{mph}$ 'limits' on the wide range of possible public health outcomes and no attempts have been made to identify differences in the effectiveness of the two intervention approaches. Therefore, the current review was conducted to address this gap in the evidence and to further the field of transport and public health.

The aim of this review was to examine the effects of both $20 \mathrm{mph}$ speed 'zones' and speed 'limits' on relevant public health outcomes. The review also assesses whether there are differences in the effectiveness of $20 \mathrm{mph}$ 'zones' compared with $20 \mathrm{mph}$ 'limits'.

\section{METHODS}

The current study was reported in accordance with PRISMA guidelines (Moher et al., 2009). The initial searches established that studies were too heterogeneous to be combined in a meta-analysis as they used differing methodologies and varied outcome measures. Therefore, a systematic review using a meta-narrative method was undertaken. The meta-narrative method enabled the research team to implement a flexible and complementary approach to interrogate the field of $20 \mathrm{mph}$ speed 'zones' and 'limits' (Wong et al., 2013) guided by the logic model framework of Rohwer et al., (2016). A metanarrative method was implemented over a realist approach as it provided the research team with an appropriate method to summarise the included studies which conceptualised the $20 \mathrm{mph}$ schemes differently and presented inconsistent methods and analysis procedures (Wong et al., 2013). This was thought to be a more suitable approach in comparison to a realist review where the focus is often on the theories of behaviour change (Otte-Trojel and Wong, 2016). Consequently, RAMESES guidelines and publication standards were implemented within the current review (Wong et al., 2013). 


\section{Meta-narrative review principles}

A meta-narrative approach made it possible to review the subject of $20 \mathrm{mph}$ 'zones' and 'limits' and to summarise results in a meaningful way (Wong et al., 2013). The current review implemented the six guiding principles of the meta-narrative method: pragmatism (guided by the most useful information for the intended audience); pluralism (the topic reviewed to consider multiple perspectives and viewpoints); historicity (the topic reviewed over time i); contestation (conflicting data considered); reflexivity (take time to reflect on the findings, individually and as a review team); and peer review (findings shown to an independent audience and the feedback used to guide further reflection) (Greenhalgh et al., 2005).

\section{Search strategy}

A review of the literature was conducted and each member of the team provided with the opportunity to present documents for inclusion (pragmatism) (Wong et al., 2013; Greenhalgh et al., 2005). Following the review, a comprehensive search strategy was devised for English language articles from 1983 (when the first 30kph/20mph 'zone' was implemented) to January 2019 in MEDLINE, EMBASE, Web of Science and Transport Research Information Service. Databases were searched using a tailored search strategy, consisting of the AND combination of the two main concepts, $20 \mathrm{mph}$ and health, and the OR combination of all keyword variations (Appendix 1). Reference lists and relevant systematic reviews were also searched for other potentially eligible studies. To complement these searches, grey literature was searched using: 20's Plenty, The Royal Society for the Prevention of Accidents (RoSPA), UK Roads Liaison Group, and Department of Transport.

Inclusion criteria:

1. Natural experiments with quasi-experimental design; randomised control trials; controlled before and after studies; and interrupted time series. 
2. Any age group, country and location.

3. $20 \mathrm{mph}$ or $30 \mathrm{~km} / \mathrm{h}$ speed 'zones' and $20 \mathrm{mph}$ or $30 \mathrm{~km} / \mathrm{h}$ speed 'limits' interventions (1 mile equates to $1.6 \mathrm{~km})$.

4. Studies with a comparison group.

5. At least one public health outcome reported.

\section{Screening of articles}

To ensure pluralism, a multi-disciplinary team with differing expertise undertook independent screening of titles, abstracts and full texts for eligibility. Disagreements were resolved by discussion and consensus.

\section{Data extraction}

Data were extracted including: publication year; country; study design and duration; characteristics of the intervention and control groups; outcome(s); and results. The primary outcomes extracted were: road traffic collisions and casualties (any road user). Other outcomes extracted were: physical activity levels (walking and cycling), changes in mode of transport, noise pollution, air quality, inequalities, perceptions of road safety and liveability (The Health Foundation, 2018).

\section{Quality appraisal}

Quasi-experimental designs are considered methodologically weaker for establishing causation than randomised control trials and fewer tools exist to evaluate their quality. There are some tools available to assist with assessing quality of non-randomised study designs; however, these are not specific to the included study designs and there may be issues that they do not fully address (The Joanna-Briggs Institute, 2017; Sterne et al., 2016; Sterne et al., 2016). Therefore, using the elements of these tools as a guide, the following additional data was extracted to assess study quality: the duration (attrition bias), control site including location; selection and matching (selection bias); how the data were 
collected or measured (detection bias); selective or incomplete reporting of results (reporting bias); and any other attempts to minimise sources of confounding.

\section{Evidence synthesis}

Studies were presented by method and outcome and the results were combined in a narrative review. Schemes were categorised as: 1) $20 \mathrm{mph}$ 'zones' and 2) $20 \mathrm{mph}$ 'limits'. In addition, evidence was gathered by further sub-dividing results by: 1) collisions and casualties; 2) liveability including physical activity; 3) pollution; and 4) inequalities.

During the evidence synthesis stage a comparison was performed to review the differing metanarratives and to ultimately interpret the included study findings. This stage of the review involved paradigm building and grouping by intervention approach ( $20 \mathrm{mph}$ 'zones' and $20 \mathrm{mph}$ 'limits') and outcomes (Wong et al., 2013).

\section{RESULTS}

\section{Study characteristics}

A total of 6169 studies were identified including seven studies/reports from manual searches and grey literature (Figure 1). Following duplicate removal $(n=2100), 4069$ studies were included for title/abstract screening. After initial screening, 117 studies met the eligibility criteria and following full text screening 13 papers reporting 11 studies, met the inclusion criteria (Atkins et al., 2018; Brilon Blanke, 1993; Brilon Blanke, 1990; Grundy et al., 2009; Steinbach et al., 2011; Webster et al., 2006; Layfield et al., 2003; Engel Thomsen, 1992; Webster Layfield, 2007; Li Graham, 206; Vis et al., 1992; Owen, 2005; Gaca et al., 2016).

Included studies were all European and published 1990-2018: UK (6); Demark (2); the Netherlands (1); Germany (1); and Poland (1). Four additional reports were found in the grey literature (Manchester City Council, 2017; Pilkington et al., 2018; The City of Edinburgh Council, 2013; Department for 
Transport, 2010). These were not included within the review but reported findings that warranted review were noted. Of the included studies, four were reported by more than one publication; these provided further details regarding the methodology, intervention and/or additional outcomes. Two publications reported the effect of $30 \mathrm{kmh}$ 'zones' on six towns and a pilot town in Germany and within the current review they were considered as one study (Brilon Blanke, 1993; Brilon Blanke, 1990). A study that examined $20 \mathrm{mph}$ 'zones' in London was reported in two publications each investigating different outcomes and were both presented separately within this study (Grundy et al., 2009; Steinbach et al., 2011). The results from a home zone (i.e. a shared space scheme where streets are designed for all road users) in Leeds was presented in a Transport Research Laboratory (TRL) report on pilot home zone schemes in the UK (Webster et al., 2006) but is described in more detail in an evaluation report (Layfield et al., 2003); both were presented separately in the current review (Table 1). The two final reports were published in 2018 with findings from the UK (Atkins et al., 2016) and Poland (Gaca et al., 2016).

\section{$20 \mathrm{mph}$ or $30 \mathrm{kmh}$ 'zones'}

Nine of the included studies examined the effect of $20 \mathrm{mph}$ 'zones' (Table 1).

\section{Collisions and casualties}

Overall, the nine included studies indicated that $20 \mathrm{mph}$ 'zones' are associated with a reduction in the number and severity of collisions and casualties. Brilon and Blanke $(1990 ; 1993)$ reported that the introduction of traffic calming measures was associated with an average $63 \%$ reduction in seriously injured persons; a 49\% decrease in slightly injured persons; a 40\% decrease in collision costs; a $78 \%$ decrease in motor bikers involved in a collision; a 17\% decrease in cyclists involved in a collision; and a $25 \%$ decrease in pedestrians involved in a collision (Brilon and Blanke, 1990; 1993). Similarly, Engel and Thomsen (1992) found $30 \mathrm{kmh}$ streets were associated with a reduction in the number of collisions $(24 \%, n=77)$ and casualties $(45 \%, n=88)$ and changes were also observed in the street 
sections just outside the $30 \mathrm{kmh}$ zones with an $18 \%$ reduction in collisions and a $21 \%$ reduction in casualties (Engel and Thomsen, 1992). Additional findings showed collisions and casualties were related to the number of road users (including pedestrians, pedal cyclists and moped riders) kilometres travelled in each street; with the main effect showing a significant reduction in the number of casualties per road user $\mathrm{km},(72 \%$ [95\% $\mathrm{Cl}-4$ to $-92 \%])$ and a significant reduction in the number of seriously injured casualties (78\% [95\% Cl -26 to -93\%]) (Engel and Thomsen, 1992).

Grundy et al., (2009) reported that 20 mph 'zones' were associated with reductions of: $41.9 \%(95 \% \mathrm{Cl}$ 36.0 to 47.8$)$ in all casualties; $32.4 \%(95 \% \mathrm{Cl} 27.1$ to 37.7$)$ in all pedestrian casualties; $16.9 \%(95 \% \mathrm{Cl}$ 4.8 to 29.0$)$ in all cyclist casualties; $32.6 \%(95 \% \mathrm{Cl} 21.7$ to 43.4$)$ in all causalities of powered two wheeled vehicle riders; $52.5 \%(95 \% \mathrm{Cl} 42.5$ to 62.4$)$ in all car occupant causalities; and $37.5 \%(95 \% \mathrm{Cl}$ 31.6 to 43.4 ) in all collisions. The greatest reductions were found in the killed or seriously injured (KSI) category and in those aged 0-15 years. In addition, an $8.0 \%$ (95\% $\mathrm{Cl} 4.4$ to 11.5$)$ reduction in casualties and a $7.4 \%(95 \% \mathrm{Cl} 3.8$ to 11.0$)$ reduction in collisions were also observed in areas adjacent to the 20 mph 'zones' (Grundy et al., 2009). Li and Graham (2016) reported that the $20 \mathrm{mph}$ 'zones' had a consistently significant impact on casualties, reducing by number. Specifically, they concluded, that 20 mph 'zones' were associated with reductions in slightly injured casualties (1.7 [10\%], KSI $(0.73$ [24\%]); and pedestrian casualties (0.85 [21\%) (Li and Graham, 2016). Vis et al., 1992 (62) reported a $5 \%$ reduction in collisions with the implementation of $30 \mathrm{kmh}$ 'zones', after adjustment for local trend. This reduction was greater (25\%) in collisions involving injury.

Webster and Layfield (2003) reported highly statistically significant $(p<0.01)$ reductions in collision and casualty frequency associated with $20 \mathrm{mph}$ 'zones' (43\% and 46\% respectively) before correction for local trends. When full allowance is made for trends on unclassified roads, these values are revised to a $41 \%$ reduction in collisions and a $45 \%$ reduction in casualties (Webster and Layfield, 2003). This adjustment assumes the introduction of $20 \mathrm{mph}$ 'zones' has had no effect on the unclassified roads, 
whereas in reality they will have contributed to this underlying trend. The study therefore suggests that the effect of $20 \mathrm{mph}$ 'zones' is better interpreted as bringing about a reduction of somewhere between the two values (a 41-43\% reduction in all collisions and a $45-46 \%$ reduction in all casualties) (Webster and Layfield, 2003). Statistically significant reductions were also observed in pedestrian, cyclist, powered two wheeled vehicle and car occupant casualties. Layfield et al., (2003) found that the 'before' frequency of collisions within the 'zone' was 0.4 per year versus 0 in the year 'after' the 'zone'; 2.2 per year at junctions leading into the 'zone' versus 1 in the year 'after'; and 2.2 per year on the perimeter roads outside the 'zone' 'before' versus 0 in the year 'after'.

Webster et al., (2006) detailed results from a seven site (Leeds, Manchester, Sittingbourne, Magor, Plymouth, Nottingham, Ealing) traffic management scheme including the study previously presented in Leeds. Road traffic injury collisions were analysed across the seven study sites with findings showing a reduction from 0.54 to 0.24 collisions per site per year. Self-reported collisions and near misses were also found to decrease after installation of the traffic calming 'zones' (Webster et al., 2006). Although some of these findings are statistically significant, they are rare events, and random fluctuations may be impacting the significance.

\section{Liveability including physical activity}

Layfield et al., (2003) and Webster et al., (2006) reported walking and cycling changes following the implementation of schemes in Leeds (Layfield et al., 2003) and across seven English sites (including Leeds) (Webster et al., 2006). Regarding walking, for most respondents the introduction of the scheme did not make a difference because levels of walking were already high. However, in Leeds $73 \%$ of participants reported that walking in the home zone was now more pleasant (Layfield et al., 2003), while the figure was $44 \%$ overall across the seven sites (Webster et al., 2006). The reasons reported for walking being more pleasant were linked to slower traffic and less traffic. Approximately $21-25 \%$ reported to own a bicycle with 'use' being found to be low at both time points (Leeds and wider study 
areas); implementation of $20 \mathrm{mph}$ 'zones' made no difference. However, for those who did cycle in Leeds the scheme made cycling more pleasant for 50\% (approximately) due to less traffic and good cycle surface, in Ealing $60 \%$ thought cycling was more pleasant and $10 \%$ thought it was less pleasant. Of the children who cycled $22-27 \%$ said they cycled more due to scheme implementation and $57-73 \%$ said they rode about the same (lower levels overall across the seven sites).

Both studies also reported activities in the street/outside the home for adults and children. Following the implementation of the home zone the majority of adults said the zone made no difference to the amount of time they spend outside; and overall there were only little changes in the activities of children. The proportion of children reporting "spontaneously" riding bikes in Leeds increased substantially from $22 \%$ to $43 \%$ and the use of roller skates and skateboards also increased from $11 \%$ to $19 \%$. In addition, Vis et al., (1993) reported that residents felt safer as they believed that speed and the intensity of traffic had declined.

\section{Pollution}

Three studies (Webster et al., 2006; Layfield et al., 2003; Owen, 2005) examined the effect of $20 \mathrm{mph}$ 'zones' on air quality by measuring benzene and nitrogen dioxide $\left(\mathrm{NO}_{2}\right)$ in ambient air before and after implementation (Table 1). For similar periods, without missing data, Layfield et al., (2003) found marginal increases in benzene at intervention sites compared with the control site and marginal decreases in $\mathrm{NO}_{2}$ at intervention sites, compared with the control site. The concentrations of benzene and $\mathrm{NO}_{2}$ were below Air Quality Standards ( $5 \mu \mathrm{g} / \mathrm{m3}$ and $40 \mu \mathrm{g} / \mathrm{m} 3$ respectively) at all sites, both before and after implementation (Department for Environmental Food and Rural Affairs, 2018).

Owen (2005) found increases in benzene and $\mathrm{NO}_{2}$ at one intervention site, and decreases in both at a second site (Owen, 2005). All observed changes in both studies, were small and not statistically significant. 


\section{Inequalities}

Only one study looked at the effect of 20 mph 'zones' on inequalities (Table 1) (Steinbach et al., 2011). It found that $20 \mathrm{mph}$ 'zones' have similar effects across all quintiles of socio-economic deprivation in terms of pedestrian, KSI and all casualties. Similarly, areas adjacent to $20 \mathrm{mph}$ 'zones' also experienced a decline in casualties that was consistent across quintiles of socioeconomic deprivation. A higher number of casualties usually occurs in deprived areas, and as such $20 \mathrm{mph}$ 'zones' have been implemented in the most deprived areas. Therefore, the number of casualties prevented by $20 \mathrm{mph}$ 'zones' was significantly greater in the most deprived areas compared with the least. Despite this, the underlying trend of casualty rate reduction on all roads is greatest in the least deprived quintile. However, the study concluded that $20 \mathrm{mph}$ 'zones' may be effective in reducing this widening of inequalities.

\section{$20 \mathrm{mph}$ or $30 \mathrm{kmh}$ 'limits'}

Two included studies examined the effect of 20 mph 'limits' (Table 2) (Atkins et al., 2018; Gaca et al., 2016).

\section{Collisions and casualties}

Both studies, showed, that $20 \mathrm{mph}$ 'limit' were effective in improving road safety. Gaca et al. (2016) used crash modification factors (CMF) scores to evaluate how $30 \mathrm{kmh}$ speed 'limits', and other road safety measures and designs, affect road safety (Gaca et al., 2016). To determine the potential safety effect of an intervention the change in the number crashes was compared. A CMF score was then applied to the number of crashes before the intervention to calculate the expected number of crashes after implementation at a specific site. The study stated that area speed limits were effective in improving road safety. A reduction in KSI casualties was reported following the introduction of $20 \mathrm{mph}$ and 30 mph 'zones' (CMF [-] of 0.65 in treated group, compared with 0.74 in the control group). 
However, no positive effects on collision reduction were observed. No confidence intervals or hypothesis tests were presented. It was also stated that area speed limits were especially effective when combined with traffic calming measure, however, it was not clear how this was calculated.

Atkins et al., (2018) evaluated 12 case study schemes comparing them to comparator areas with 30 mph speed 'limits'. Regarding public health outcomes, the report showed that there was insufficient evidence to conclude that there was a significant change in both collisions and casualties in $20 \mathrm{mph}$ speed 'limit' areas. It was noted that the number of both collisions and casualties had declined in the $20 \mathrm{mph}$ areas but this was also the case in the $30 \mathrm{mph}$ areas (Atkins et al., 2018).

\section{Liveability including physical activity}

Only one study reported outcomes relating to liveability. Of residents, drivers and exiting cyclists ( $n=1965$ (all schemes) 69\% felt the speed limits were thought to be beneficial for both cyclists and pedestrians and $60 \%$ felt the limits "provided a safer environment for walking and cycling" (Atkins et al., 2018). Of those who currently cycled $66 \%$ felt $20 \mathrm{mph}$ provide a safer environment for cycling. The process and impact report also showed that there has been a small (but significant) increase in the proportion stating that they have increased their use of active travel mode; but a minority said that keeping traffic below $20 \mathrm{mph}$ makes it more likely they will walk $(16 \%)$ or cycle $(9 \%)$ rather than drive (Atkins et al., 2018).

\section{0 mph speed 'limits' - grey literature}

Additional grey literature was found for before and after evaluations of $20 \mathrm{mph}$ speed 'limits'. These interventions were implemented in Manchester (Manchester City Council, 2017), Bristol (Pilkington et al., 2018), Edinburgh (The City of Edinburgh Council, 2013) and Portsmouth (Department for Transport, 2010). The studies were not included within the main body of the current review as they 
did not include a control group; however, it was felt that it would be beneficial to highlight their findings.

The interventions showed on average $20 \mathrm{mph}$ 'limits' were associated with a reduction in vehicle speeds of $0.7 \mathrm{mph},-29 \%$ (673 to 444 ) citywide rate of pedestrian collisions and $-42 \%$ (475 to 274 ) citywide rates of cyclist collisions. However, casualty figures could not be reported confidently, due to the time frame (Manchester) (Manchester City Council, 2017). In Bristol comparison data for speed but not for public health outcomes was presented (which could not be included within the main body of the review); found speed reduced significantly by $0.8-2.7 \mathrm{mph}$ dependent on the measurement method (controlled) (Pilkington et al., 2018). In addition, casualties reduced, fewer residents were disturbed by traffic noise and walking to work increased $17.5-18.9 \%$. Furthermore, the number of people driving to work decreased by $53-44 \%$, and the number of cyclists increased by $11-15 \%$ following limit introduction (Pilkington et al., 2018).

Within Edinburgh's Pilot evaluation in one part of the city, reports showed speed reduced on average by $1.9 \mathrm{mph}$ on $20 \mathrm{mph}$ roads (The City of Edinburgh Council, 2013). Figures for casualties/collisions could not be reported due to the monitoring time frame although support for the scheme increased from $68 \%$ before to $79 \%$ after (The City of Edinburgh Council, 2013). Finally, in Portsmouth speed reduced by $-1.3 \mathrm{mph}$; collisions fell by $21 \%$ per year; casualties fell by $22 \%$ per year; and walking (+9.2\%) and cycling (+8.0\%) increased (The City of Edinburgh Council, 2013).

\section{Quality and risk of bias in the included studies}

Overall, the included studies were generally at a high risk or unclear risk of selection bias and bias due to confounding (Table 3). This may be due, in part to the natural experiment study design, as the investigators had limited control over the intervention and control areas. In terms of selection bias, three studies reported matching of the control group, although details are only provided by one study. 
The control groups for the remaining studies $(n=8)$ were untreated roads in the areas under analysis. The majority of studies $(n=7)$ used routinely collected police data, therefore, risk of detection bias is low as the data were produced and maintained by an external source. The source of data was unclear for two studies, and in a further two studies, measurements were taken by the study team. In addition, the before and after periods varied widely between studies: the majority of studies included at least one year before and after data $(n=7)$. In terms of reporting bias, several studies did not clearly report their data, statistical methods or how conclusions were reached, and one study excluded an intervention area from analysis because it had shown an increase in collision figures. Three studies combined an intervention of interest with another intervention, and as insufficient data were provided to distinguish the effects of the intervention of interest, it was difficult to interpret the results of these studies in the context of this review. Other potential sources of bias, or attempts to minimise confounding are noted in Table 3.

\section{DISCUSSION}

The aim of the current review was to investigate the effect of $20 \mathrm{mph}$ speed 'zones; and limits on public health outcomes and to establish differences in the effectiveness of zones compared with limits.

Based on the evidence, the effect of $20 \mathrm{mph}$ 'zones' on public health outcomes is positive. In particular, there were significant reductions in collisions and/or casualties. In regards to $20 \mathrm{mph}$ 'limits', the evidence based was more limited and results were not as clear, and limited in regards to their examination of liveability, pollution or inequalities.

$20 \mathrm{mph}$ 'zones' were found to have the potential to significantly reduce road traffic deaths and injuries. However, a concern is that $20 \mathrm{mph}$ 'zones' will lead to a relocation of collisions rather than prevention. This is addressed in several studies, which also report a reduction in collisions and casualties in areas adjacent to $20 \mathrm{mph}$ 'zones', suggesting that collision migration is unlikely (Grundy 
et al., 2009; Engel and Thomsen, 1992; Webster and Layfield, 2007). In addition, the included studies report a general reduction in collisions and casualties in control groups, but to a lesser extent than intervention areas. This may suggest that other road safety interventions are in place simultaneously, highlighting the need for a control group, as the comparison allows the results to more accurately reflect the effect of $20 \mathrm{mph}$ 'zones'.

Regarding pollution, less robust evidence of the effect of $20 \mathrm{mph}$ 'zones' on air pollution was found. A potential reason may be due to the fact that speed, driving style and congestion play a role in vehicle emissions and some vehicles operate most efficiently at higher speeds, so low speeds may increase emissions whilst decreasing efficiency (Transport for London, 2018). Conversely, slower speeds may promote smoother driving, meaning reduced acceleration and braking, in turn having a positive effect; and the health impact of small increases in air pollutants may be outweighed by the reduced risk of injuries and death by decreased speed. Air quality is a contributor to several of the United Nations Sustainable Development Goals (SDGs) (4), including SDG 3: Good Health and Wellbeing, SDG 11: Sustainable Cities and Communities and SDG 15: Life on Land (United Nations, 2016). Therefore, interventions that improve air quality are vital to achieving these goals. It is clear that the effect of transport on vehicle emissions can be complex and conflicting, and so further investigation is required to fully understand the effect of $20 \mathrm{mph}$ 'zones' on air quality and the mechanisms by which such change is brought about. This review found that on a small scale, the introduction of 20 mph 'zones' had no significant effect on ambient air quality in terms of $\mathrm{NO}_{2}$ and benzene. Finally, it should be noted that due to the difficulty in measuring air pollution in comparison to other public health outcomes this should be considered and reflected upon as a factor in the quality of the evidence.

In relation to liveability, results showed for included studies, participants reported to walk more and found the environment more pleasant due to slower and less traffic. Neighbourhood 'pleasantness' also increased for those who already cycled and an increase was seen in children spontaneously 
cycling. $20 \mathrm{mph}$ speed 'zones' have the potential to indirectly impact physical activity and liveability through various mechanisms for change although currently the evidence is lacking and requires further work. Similarly, research is lacking in regards to $20 \mathrm{mph}$ restrictions and health inequalities; only one included study concluded that $20 \mathrm{mph}$ 'zones' are equally effective in reducing casualties across all quintiles of socioeconomic deprivation, and may serve to alleviate the widening of inequalities. While further research is required, $20 \mathrm{mph}$ 'zones' may have potential in helping to improve liveability and to achieve SDG 10: Reduced Inequalities (United Nations, 2016).

\section{Comparison of $20 \mathrm{mph}$ speed 'zones' and 'limits'}

To date, no review has performed a comparison between speed limits and zones. As discussed, the evidence suggests that $20 \mathrm{mph}$ 'zones' are effective. However, there was a lack of evidence on the effectiveness of $20 \mathrm{mph}$ speed 'limits'. Only two studies reported the effects of $20 \mathrm{mph}$ speed 'limits' (signage). Gaca et al., 2016 reported no significant effect on collisions, although did find that $20 \mathrm{mph}$ speed 'limits' were associated with a reduction in KSI casualties. The sample was small and based on only lower class roads, therefore the results may not be applicable in a wider context. Atkins et al., (2018) reported that although collisions and casualties decreased the time was too short to see significant changes when compared with control/comparison sites. Grey literature highlighted the results of four additional interventions which appear to have positive public health outcomes. These findings should be considered and reviewed within the context of the current evidence although taken into consideration they had no control/comparison sites, so it is difficult to isolate specific intervention effects.

More research has been carried out for $20 \mathrm{mph}$ 'zones' as opposed to $20 \mathrm{mph}$ 'limits'. This is not to say that $20 \mathrm{mph}$ speed 'limits' are not effective in improving public health outcomes and current research would indicate that they have the potential to be successful, but more work is required to 
evaluate the schemes with comparison/control sites in order to isolate the effect(s) of the interventions in relation to public health outcomes.

\section{Completeness and applicability of evidence}

The included studies were all implemented within urban areas in high income countries with results being found to be consistent across locations. Further research would however be recommended in order to determine if the results are applicable to rural areas; which tend to have higher speed limits (60 $\mathrm{mph}$ ), which is often unsuitable for the design and condition of the road, particularly considering their use by vulnerable road users. In addition, speeding often occurs in villages on major rural roads despite a reduced speed limit on through roads (Department for Transport, 2007). Research is also required in low-middle income countries which make up a large proportion of road traffic injuries, due in part to the rapid increase in vehicle use that has not been matched with policy updates, infrastructure improvements and enforcement (WHO, 2015). Traffic calming measures have previously been shown to be effective, in both rural areas ${ }^{58}$ and low-middle income countries (Staton et al., 2016). Therefore, it is possible that 20 mph 'zones', particularly in areas with high rates of speed related collisions, would be beneficial in reducing collision and casualty rates.

Despite the popularity of $20 \mathrm{mph}$ 'zones' and 'limits', many of the included studies were published in the 1990s and 2000s (20's Plenty for Us, 2015). Changes in infrastructure and traffic volume, (increase in the number of roads, car users and cyclists), since this time, bring into question the applicability of the results; only four studies (30\%) were from the last 10 years (Department for Transport, 2017).

\section{Quality and limitations of the evidence}

The quality of the evidence is dependent on the quality of its included studies. This review found no randomised controlled trials that met the inclusion criteria, and all included studies were quasiexperimental design, with the majority being controlled before and after studies. This introduced 
potential biases as little detail was provided on selection and matching of control groups, and therefore their characteristics may differ from those of the intervention group. One study used a doubly robust estimation which included extensive matching of the control streets to the intervention streets. While the results were consistent with the reductions reported by others, the estimates were smaller (Li and Graham, 2016). This could be due to selection bias in the other studies leading to an overestimation of the effects.

With a few exceptions, where details of the study periods were not provided (Vis et al., 1992) or where stated that measurements were undertaken at the same time of year (Layfield et al., 2003; Owen, 2005), all studies included before and after periods of at least one year; this is important due to the seasonal variation in traffic patterns. It should be noted that it was not always possible to determine how the results from each study were obtained and several studies did not provide confidence intervals or significance data. Furthermore, some of the studies did not examine $20 \mathrm{mph}$ 'zones' exclusively (Brilon and Blanke, 1990; 1993; Engel and Thomsen, 1992; Gaca et al., 2016).

As mentioned in several of the studies, a limitation is inaccurate and incomplete data in police records. There is typically an under reporting of collisions in police records, and misclassification of collisions. Furthermore, the studies were unable to account for other road safety measures, in either the control or intervention group (e.g. traffic volume and weather). However, this is likely to be the same across intervention and control areas. Few studies measured the negative impact of such interventions or captured unintended consequences. For example, we could hypothesise that these road safety measures may affect trip making, mode choice and route choice. Further, we were unable to draw conclusions regarding the impact of collision migration to non-adjacent zones. Such measures should be considered in future studies.

\section{Potential biases and limitations of this study}


The number of relevant studies may have been limited by English language. The high proportion (50\%) of studies from the UK may be evidence of this, particularly considering the popularity of such zones in residential areas across Europe (20's Plenty for Us, 2015). Secondly, it should be noted that even though a comprehensive search was undertaken, publication and selection biases may have been possible. This relates to the fact that many studies on road traffic safety, are found in grey literature in the form of reports by charities, governments and local councils, rather than peer reviewed papers, and many are publicly unavailable. In addition, the study design and reporting style varied between studies and relevant data were not always provided or able to be extracted. Most studies included only short follow-up periods of one year. Longer follow-up periods are required in order to mitigate the effects of regression to the mean. Evidence synthesis was therefore presented narratively, thus the conclusions are less certain.

\section{CONCLUSIONS}

This review found that $20 \mathrm{mph}$ 'zones' appear to be effective, in particular in reducing the number and severity of collisions and casualties. However, it provides insufficient evidence to draw robust conclusions on the effect of $20 \mathrm{mph}$ 'zones' on liveability, air quality and inequalities, or on the effect of $20 \mathrm{mph}$ speed 'limits' on these public health outcomes. Therefore, regarding the comparison of the effects of $20 \mathrm{mph}$ 'zones' in comparison to $20 \mathrm{mph}$ 'limits', 'zones' appear to be more effective although as the work in this field is limited more research is required to determine a direct comparison with speed limits as the majority of current research is limited by lack of control/comparison sites and time frames.

In practice, the implementation of $20 \mathrm{mph}$ 'zones' appears promising, although based on this review may be restricted to towns and cities in higher income countries. Further research is required in order to ascertain the extent of their effectiveness. In addition, their future and continued benefit may also 
be limited in those settings where they have already been widely implemented (Grundy et al., 2009; Steinbach et al., 2011).

This review highlights the need for high quality controlled evaluations, to provide more robust results. Additionally, there is a need for data from interventions and control groups to be reported transparently, this would allow data extraction, comparison and pooling of results from similar studies. Furthermore, it would enable researchers to determine the specific effective and ineffective components of both $20 \mathrm{mph}$ 'zone' and 'limit' interventions.

\section{Acknowledgements}

Not applicable.

\section{Funding}

Funding statement blinded for peer review.

\section{REFERENCES}

Atkins, AECOM, Maher M. 20 mph Research Study. Process and impact evaluation technical report, 2018. Available from:

https://assets.publishing.service.gov.uk/government/uploads/system/uploads/attachment data/file /757302/20mph-technical-report.pdf

Brilon W, Blanke H. Extensive Traffic Calming: Results of the accident analyses in 6 model towns. In: (ITE), Institute of Transportation Engineers, 1993;119-23.

Brilon W, Blanke H. Traffic safety effects from traffic calming. VTI Rapp. 1990;363A:134-48. 
Braveman P, Egerter S, Williams DR. The Social Determinants of Health: Coming of Age. Annu Rev Public Health. 2011;42(4):768-72.

British Heart Foundation. Physical inactivity and sedentary behaviour report 2017. British Heart Foundation 2017. Available from: https://www.bhf.org.uk/publications/statistics/physical-inactivity$\underline{\text { report-2017 }}$

Cairns J, Warren J, Garthwaite K, Greig G, Bambra C. Go slow: an umbrella review of the effects of 20 mph zones and limits on health and health inequalities. J Public Health. 2015;37(3):515-20.

Department for Environment Food and Rural Affairs. Emissions of air pollutants in the UK, 1970 To 2016. 2018:13. Available from:

https://assets.publishing.service.gov.uk/government/uploads/system/uploads/attachment data/file $681445 /$ Emissions of air pollutants statistical release FINALv4.pdf

Department for Transport. Interim evaluation of the implementation of $20 \mathrm{mph}$ speed limits in Portsmouth. 2010. Available from:

http://www.wirralpedestrians.org.uk/files/20mphzoneresearch.pdf

Department for Transport. Road traffic estimates: Great Britain 2016. 2017. Available from: https://assets.publishing.service.gov.uk/government/uploads/system/uploads/attachment data/file 611304/ann ual-road-traffic-estimates-2016.pdf 
Department for Transport. Table RAS50001: Contributory factors in reported accidents by severity, Great Britain, 2016-2017. Available from: https://www.gov.uk/government/statistical-datasets/ras50-contributoryfactors\#table-ras50001

Department for Transport. Traffic calming 2007. Available from:

https://www.gov.uk/government/uploads/system/uploads/attachment data/file/329454/Itn-1$\underline{07 \text { Trafficcalming.pdf }}$

Department for Transport. Traffic calming in villages on major roads. 2000. p. 8p. Available from: http://www.dft.gov.uk/pgr/roads/tpm/tal/

Engel U, Thomsen LK. Safety effects of speed reducing measures in Danish residential areas. Accid Anal Prev. 1992;24(1):17-28.

Gaca S, Kiec M, Budzynski M. Evaluating the effectiveness of non-physical speed management measures. International Conf Traffic Transp. 2016;9:627-33.

Greenhalgh T, Robert G, Macfarlane F, Bate P, Kyriakidou O, Peacock R: Storylines of research in diffusion of innovation: a meta-narrative approach to systematic review. Soc Sci Med 2005, 61:417430.

Grundy C, Steinbach R, Edwards P, Green J, Armstrong B, Wilkinson P. Effect of 20 mph traffic speed zones on road injuries in London, 1986-2006: Controlled interrupted time series analysis. BMJ. 2009;339(7736):31. 
Hart J, Parkhurst G. Driven To excess: Impacts of motor vehicles on the quality of life of residents of three streets in Bristol UK. World Transp Policy Pract. 2011;17(2):12-30.

Heath GW, Brownson RC, Kruger J, Miles R, Powell KE, Ramsey LT, et al. The effectiveness of urban design and land use and transport policies and practices to increase physical activity: a systematic review. J Phys Act Heal. 2006;3(1):55-76.

Holt-Lunstad J, Smith TB, Baker M, Harris T, Stephenson D. Loneliness and social isolation as risk factors for mortality: A meta-analytic review. Perspect Psychol Sci. 2015;10(2):227-37.

Jackson L Cracknell R. Road accident casualties in Britain and the world. House of Commons Library. 2018. Available from: http://researchbriefings.files.parliament.uk/documents/CBP-7615/CBP7615.pdf Jones SJ, Brunt H. Twenty miles per hour speed limits: A sustainable solution to public health problems in Wales. J Epidemiol Community Health. 2017;71(7):699-706.

Khreis $H$, May AD, Nieuwenhuijsen MJ. Health impacts of urban transport policy measures: A guidance note for practice. J Transp Heal. 2017;6:209-27.

Layfield R, Nicholls D, Transport Research L, Chinn L. Pilot home zone schemes: evaluation of The Methleys, Leeds. Transport. 2003. Available from: https://trl.co.uk/reports/TRL586

Li H, Graham DJ. Quantifying the causal effects of $20 \mathrm{mph}$ zones on road casualties in London via doubly robust estimation. Accid Anal Prev. 2016;93:65-74. 
Lobjois R, Cavallo V. Age-related differences in street-crossing decisions: The effects of vehicle speed and time constraints on gap selection in an estimation task. Accid Anal Prev. 2007;39(5):934-43.

Manchester City Council. Manchester City Council Report for Resolution. Evaluation of phase 1 and 2 of $20 \mathrm{mph}$ programme. 2017. p. 1-10. Available from:

https://d3n8a8pro7vhmx.cloudfront.net/20splentyforus/pages/215/attachments/original/14892361 $\underline{06 / 1620 \mathrm{mph} \text { Speedlimits.pdf?1489236106 }}$

Marmot M, Bell R. Fair society, healthy lives. Public Health. 2012;126(1):4-10.

Moher D, Liberati A, Tetzlaff J, Altman DG, Altman D, Antes G, et al. Preferred reporting items for systematic reviews and meta-analyses: The PRISMA statement. PLoS Med. 2009;6(7).

Otte-Trojel T, Wong G. Going beyond systematic reviews: Realist and meta-narrative reviews. Stud Health Technol Inform. 2016;222: 275-287.

Owen B. Air quality impacts of speed-restriction zones for road traffic. Sci Total Environ. 2005;340(13):13- 22.

Panter J, Heinen E, Mackett R, Ogilvie D. Impact of new transport infrastructure on walking, cycling, and physical activity. Am J Prev Med. 2016;50(2):45-53.

Pilkington P, Bornioli A, Bray I, Bird E. The Bristol Twenty Miles Per Hour Limit Evaluation (BRITE) Study Analysis of the $20 \mathrm{mph}$ rollout project. 2018. Available from: http://eprints.uwe.ac.uk/34851/1/BRITEBristol 20mph limit evaluation report final.pdf 
Richards D. Relationship between speed and risk of fatal injury: Pedestrians and car occupants, 2010. Available from:

http://www.dft.gov.uk/pgr/roadsafety/research/rsrr/theme5/researchreport16/doc/rswp16.doc

Rohwer A, Pfadenhauer L, Burns J, et al. Series: Clinical Epidemiology in South Africa. Paper 3: Logic models help make sense of complexity in systematic reviews and health technology assessments. J Clin Epidemiol 2017;83:37-47.

Royal College of Physicians and the Royal College of Paediatrics and Child Health. Every breath we take. The lifelong impact of air pollution. 2016. Available from:

https://www.rcplondon.ac.uk/projects/outputs/every-breath-we-take-lifelong-impact-air-pollution

Sallis JF, Bowles HR, Bauman A, Ainsworth BE, Bull FC, Craig CL, et al. Neighborhood environments and physical activity among adults in 11 countries. Am J Prev Med. 2009;36(6):484-90.

Staton C, Vissoci J, Gong E, Toomey N, Wafula R. Road traffic injury prevention initiatives: A systematic review and metasummary of effectiveness in low and middle income countries. Plos One 2016;1-15.

Steinbach R, Grundy C, Edwards P, Wilkinson P, Green J. The impact of $20 \mathrm{mph}$ traffic speed zones on inequalities in road casualties in London. J Epidemiol Community Health. 2011;65(10):921-6.

Sterne JAC, Hernán MA, Reeves BC, Savović J, Berkman ND, Viswanathan M, et al. The Risk Of Bias In Non-randomized Studies of Interventions (ROBINS-I) assessment tool (version for cohort-type studies). BMJ 2016; 355. 
Sterne JAC, Higgins JPT, Elbers RG, Reeves BC and the development group for ROBINS-U. Risk Of Bias In Non-randomized Studies of Interventions (ROBINS-I): detailed guidance. 2016;1-53. Available from: http://riskofbias.info

Tapp A, Nancarrow C, Davis A. Support and compliance with $20 \mathrm{mph}$ speed limits in Great Britain. Transp Res Part F Traffic Psychol Behav. 2015;31:36-53.

The City of Edinburgh Council. South Central Edinburgh 20mph limit pilot evaluation. 2013. Available from:

http://www.edinburgh.gov.uk/downloads/file/7820/south_central_edinburgh_20mph_limit_pilot_e valuation_2013

The Health Foundation. What makes us healthy? An introduction to the social determinants of health. 2018. Available from: https://www.health.org.uk/sites/default/files/What-makes-ushealthy-quick-guide.pdf

The Joanna Briggs Institute. Checklist for quasi-experimental studies, 2017. Available from: http://joannabriggs.org/assets/docs/critical-appraisal-tools/JBI Quasi-

Experimental Appraisal Tool2017.pdf

Toy S, Tapp A, Musselwhite C, Davis A. Can social marketing make $20 \mathrm{mph}$ the new norm? J Transp Heal. 2014;1(3):165-173.

Transport for London. Speed, emissions health. The impact of vehicle speed on emissions health: an evidence summary. 2018. Available from: 
https://www.cityoflondon.gov.uk/business/environmental-health/environmental-protection/airquality/Documents/air quality supply chain guide 2018.pdf

United Nations. Mobilizing sustainable transport for development. 2016. Available from:

https://sustainabledevelopment.un.org/content/documents/2375MobilizingSustainableTransport.p

df

Vis A, Dijkstra A, Slop M. Safety effects of $30 \mathrm{Km} / \mathrm{H}$ zones in The Netherlands. Accid Anal Prev. 1992;24(1):75-86.

Wann JP, Poulter DR, Purcell C. Reduced sensitivity to visual looming inflates the risk posed by speeding vehicles when children try to cross the road. Psychol Sci. 2011;22(4):429-34.

Webb EA, Bell S, Lacey RE, Abell JG. Crossing the road in time: Inequalities in older people's walking speeds. J Transp Health. 2017;5:77-83.

Webster D, Layfield RE. Review of 20 mph zones in London Boroughs. TRL Publ Proj Rep PPR243. 2007. Available from: https://trl.co.uk/reports/PPR243

Webster D, Tilly A, Wheeler A, Nicholls D, Buttress S. Pilot home zone schemes: summary of the schemes prepared for Traffic Management Division, Department for Transport - Traffic. 2006. Available from: $\underline{\text { https://trl.co.uk/reports/TRL654 }}$

Wong G, Greenhalgh T, Westhorp G, Buckingham J, Pawson R. RAMESES publication standards: meta-narrative reviews. BMC Med. 2013;11:20. 
World Health Organisation. Global Health Risks: Mortality and burden of disease attributable to selected major risks. World Health Organization. 2009. Available from:

http://www.who.int/healthinfo/global burden disease/GlobalHealthRisks report full.pdf

World Health Organisation. Global status report on road safety. 2015. Available from:

http://www.who.int/violence injury prevention/road safety status/2013/en/\%5Cnhttp://www.wh o.int/violence injury prevention/road safety status/2015/en/

Yang L, Sahlqvist S, McMinn A, Griffin SJ, Ogilvie D. Interventions to promote cycling: Systematic review. BMJ. 2010;341(7778):870.

20's Plenty for Us. 20mph limits improve air quality where people live, 2010. Available from:

http://www.20splentyforus.org.uk/BriefingSheets/pollutionbriefing.pdf

20's Plenty for Us. 20mph limits save time and improve traffic flow, 2012. Available from:

http://www.20splentyforus.org.uk/BriefingSheets/20mph Improves Traffic Flow.pdf

20's Plenty for Us. The foundation for active travel, 2015. Available from:

http://www.20splentyforus.org.uk/Briefings/active travel foundation.pdf

20's Plenty for Us. Trendsetter cities for a 20mph speed limit. 2015. Available from:

http://en.30kmh.eu/2015/11/27/trendsetters-for-30-kmh-research-with-surprising-results/

\section{Figure 1. PRISMA Flow Diagram}

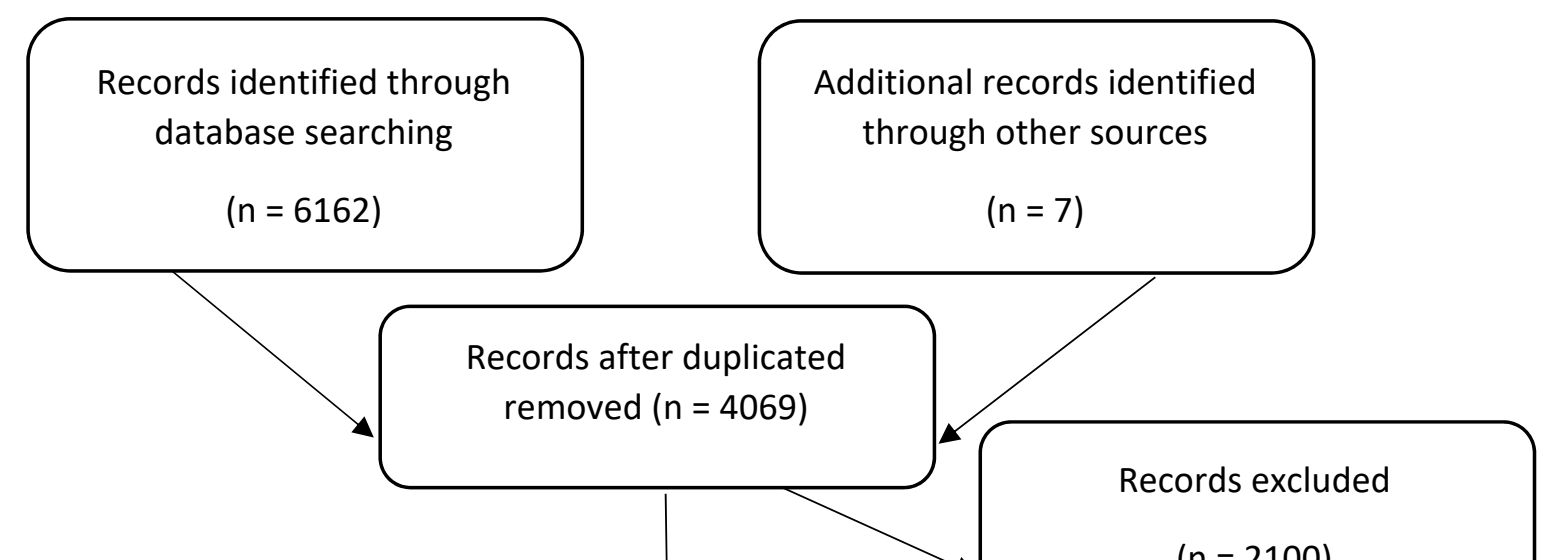


Table 1 - Characteristics and results of studies examining the effect of $\mathbf{2 0 ~} \mathbf{m p h}$ 'zones'

\begin{tabular}{|c|c|c|c|c|c|c|c|c|c|}
\hline \multirow[t]{2}{*}{ Study } & \multirow[t]{2}{*}{ Study Design } & \multirow[t]{2}{*}{ Participants } & \multirow[t]{2}{*}{ Intervention } & \multirow[t]{2}{*}{ Control } & \multirow[t]{2}{*}{ Outcome(s) } & \multicolumn{4}{|c|}{ Results } \\
\hline & & & & & & Collisions and casualties & Liveability & Pollution & Inequalities \\
\hline $\begin{array}{l}\text { Brilon and } \\
\text { Blanke (1990; } \\
\text { 1993) } \\
\text { Germany }\end{array}$ & $\begin{array}{l}\text { Controlled before and } \\
\text { after } \\
1-3 \text { years before } \\
1-3 \text { years after }\end{array}$ & $\begin{array}{l}\text { I: } 6 \text { towns in Germany } \\
\text { (plus } 1 \text { pilot area) } \\
\text { C: } 1 \text { town/area for } \\
\text { each intervention } \\
\text { (similar in structure } \\
\text { and traffic density) }\end{array}$ & $\begin{array}{l}\text { Extensive traffic calming } \\
\text { measures:30km/h speed } \\
\text { limits, passive traffic } \\
\text { calming measures and } \\
\text { street modifications }\end{array}$ & No traffic calming & $\begin{array}{l}\text { Seriously and slightly } \\
\text { injured persons } \\
\text { Collision costs } \\
\text { Motor bikers involved } \\
\text { in a collision } \\
\text { Cyclists involved in a } \\
\text { collision } \\
\text { Pedestrians involved in } \\
\text { a collision }\end{array}$ & $\begin{array}{l}63 \% \downarrow \text { in seriously injured } \\
\text { persons : } 49 \% \downarrow \text { in slightly } \\
\text { injured persons; } \\
40 \% \downarrow \text { in collision costs; } \\
78 \% \downarrow \text { in motor bikers } \\
\text { involved in a collision } \\
17 \% \downarrow \text { cyclists involved in a } \\
\text { collision } \\
25 \% \downarrow \text { in pedestrians involved } \\
\text { a collision }\end{array}$ & & & \\
\hline $\begin{array}{l}\text { Engel and } \\
\text { Thomsen } \\
\text { (1992) } \\
\text { Denmark }\end{array}$ & $\begin{array}{l}\text { Controlled before and } \\
\text { after } \\
\\
3 \text { years before } \\
3 \text { years after }\end{array}$ & $\begin{array}{l}\text { I: } 223 \mathrm{~km} \text { of } 30 \mathrm{~km} / \mathrm{h} \\
\text { streets } \\
\text { C: All urban streets in } \\
\text { Denmark that belong } \\
\text { to local government } \\
\text { authorities }(18,935 \mathrm{~km} \\
\text { of streets in total) }\end{array}$ & $\begin{array}{l}30 \mathrm{~km} / \mathrm{h} \text { speed limit } \\
\text { signage and area-wide } \\
\text { traffic calming (speed } \\
\text { humps, lateral dislocation } \\
\text { and reduced road width) }\end{array}$ & $\begin{array}{l}\text { No area wide } \\
\text { traffic calming }\end{array}$ & $\begin{array}{l}\text { Number of collisions } \\
\text { and casualties } \\
\text { Collisions and } \\
\text { casualties per } \mathrm{km} \text { of } \\
\text { road }\end{array}$ & $\begin{array}{l}\text { Sig. ( }(p<0.05) \downarrow \text { in no. of } \\
\text { collisions } \mathrm{s}(-24 \%, \mathrm{n}=77) \text { and } \\
\text { casualties }(-45 \%, \mathrm{n}=88) \text { in } \\
30 \mathrm{kmh} \text { streets; }-18 \%(\mathrm{n}=150) \\
\text { collisions and }-21 \%(\mathrm{n}=106) \text { in } \\
\text { the adjacent street sections } \\
72 \% \downarrow \text { in no. of casualties per } \\
\text { road user } \mathrm{km} ; 78 \% \downarrow \text { no. of } \\
\text { seriously injured casualties }\end{array}$ & & & \\
\hline $\begin{array}{l}\text { Grundy et al., } \\
\text { (2009) } \\
\text { UK (London) }\end{array}$ & $\begin{array}{l}\text { Controlled interrupted } \\
\text { time series } \\
\text { Implementation date } \\
\text { known for each zone, and } \\
\text { roads classified for each } \\
\text { financial year as pre- } \\
\text { intervention, under } \\
\text { construction and post } \\
\text { implementation. Before } \\
\text { and after periods varied, } \\
\text { with a maximum after } \\
\text { period of } 15 \text { years }\end{array}$ & $\begin{array}{l}\text { I: Roads in a } 20 \mathrm{mph} \\
\text { zone in London, or } \\
\text { would become part of } \\
\text { one } \\
\text { C: Areas adjacent to } \\
20 \mathrm{mph} z o n e s, \text { and all } \\
\text { other roads in London }\end{array}$ & $\begin{array}{l}20 \text { mph zones } \\
\text { Zones marked with } \\
\text { terminal signs (start and } \\
\text { end) and with traffic } \\
\text { calming measures (regular } \\
\text { intervals throughout) } \\
\text { Zone design varied } \\
\text { depending on the local } \\
\text { environment }\end{array}$ & No $20 \mathrm{mph}$ zones & $\begin{array}{l}\text { All road traffic } \\
\text { casualties } \\
\text { All pedestrian } \\
\text { casualties } \\
\text { All cyclist causalities } \\
\text { Powered two wheeled } \\
\text { vehicle rider causalities } \\
\text { All car occupants } \\
\text { All road traffic collisions }\end{array}$ & $\begin{array}{l}20 \text { mph zones: } 41.9 \%(95 \% \mathrm{Cl} \\
36.0 \text { to } 47.8) \downarrow \\
32.4 \%(95 \% \mathrm{Cl} 27.1 \text { to } 37.7) \downarrow \\
16.9 \%(95 \% \mathrm{Cl} 4.8 \text { to } 29.0) \downarrow \\
32.6 \%(95 \% \mathrm{Cl} 21.7 \text { to } 43.4) \downarrow \\
52.5 \%(95 \% \mathrm{Cl} 42.5 \text { to } 62.4) \downarrow \\
37.5 \%(95 \% \mathrm{Cl} 31.6 \% \text { to } 43.4 \%) \\
\downarrow \text { in all collisions }\end{array}$ & & & \\
\hline $\begin{array}{l}\text { Li and Graham } \\
\text { (2016) } \\
\text { UK (London) }\end{array}$ & $\begin{array}{l}\text { Doubly robust estimation } \\
\text { (combination of outcome } \\
\text { regression and propensity } \\
\text { score models) }\end{array}$ & $\begin{array}{l}\text { I: } 234 \text { treated zones in } \\
\text { London } \\
\text { C: } 2844 \text { potential } \\
\text { control zones, refined } \\
\text { to } 1415 \text { with matching } \\
\end{array}$ & $\begin{array}{l}20 \mathrm{mph} \text { zones } \\
\text { No further detail provided }\end{array}$ & No $20 \mathrm{mph}$ zones & Road traffic casualties & $\begin{array}{l}\downarrow \text { in slightly injured casualties, } \\
1.7(10 \%) \text {; KSI, } 0.73(24 \%) \text {; and } \\
\text { pedestrian casualties, } 0.85 \\
(21 \%)\end{array}$ & & & \\
\hline $\begin{array}{l}\text { Vis et al., } \\
\text { (1992) } \\
\text { Netherlands }\end{array}$ & $\begin{array}{l}\text { Controlled before and } \\
\text { after (durations not } \\
\text { provided) }\end{array}$ & $\begin{array}{l}\text { I: } 1530 \mathrm{~km} / \mathrm{h} \text { zones } \\
\text { C: Built up areas of the } \\
\text { municipalities in which } \\
\text { the zones are situated } \\
\text { (excluding arterial } \\
\text { roads) }\end{array}$ & $\begin{array}{l}30 \mathrm{~km} / \mathrm{h} \text { speed limit with } \\
\text { traffic calming measures } \\
\text { (speed humps, entrance } \\
\text { constructions, turning } \\
\text { bans, mini roundabouts } \\
\text { and traffic island) }\end{array}$ & $\begin{array}{l}\text { No area wide } \\
\text { traffic calming }\end{array}$ & $\begin{array}{l}\text { Road traffic collisions } \\
\text { and casualties }\end{array}$ & $\begin{array}{l}5 \% \downarrow \text { in all collisions and } 25 \% \\
\downarrow \text { in collisions involving injury } \\
\text { in the intervention areas after } \\
\text { adjustment for local trend) }\end{array}$ & $\begin{array}{l}\text { Residents felt safer as } \\
\text { they believed speed and } \\
\text { the intensity of traffic } \\
\text { had } \downarrow\end{array}$ & & \\
\hline $\begin{array}{l}\text { Webster and } \\
\text { Layfield (2007) } \\
\text { UK (London) }\end{array}$ & $\begin{array}{l}\text { Controlled before and } \\
\text { after }\end{array}$ & $\begin{array}{l}\text { 1: } 7820 \mathrm{mph} \text { zones in } \\
\text { London }\end{array}$ & $\begin{array}{l}20 \mathrm{mph} \text { speed limit and } \\
\text { area wide traffic calming } \\
\text { (road humps, raised }\end{array}$ & $\begin{array}{l}\text { No area wide } \\
\text { traffic calming }\end{array}$ & Road traffic collisions & $\begin{array}{l}\downarrow \text { in annual collision frequency } \\
(-43 \% ; p<0.01)\end{array}$ & & & \\
\hline
\end{tabular}




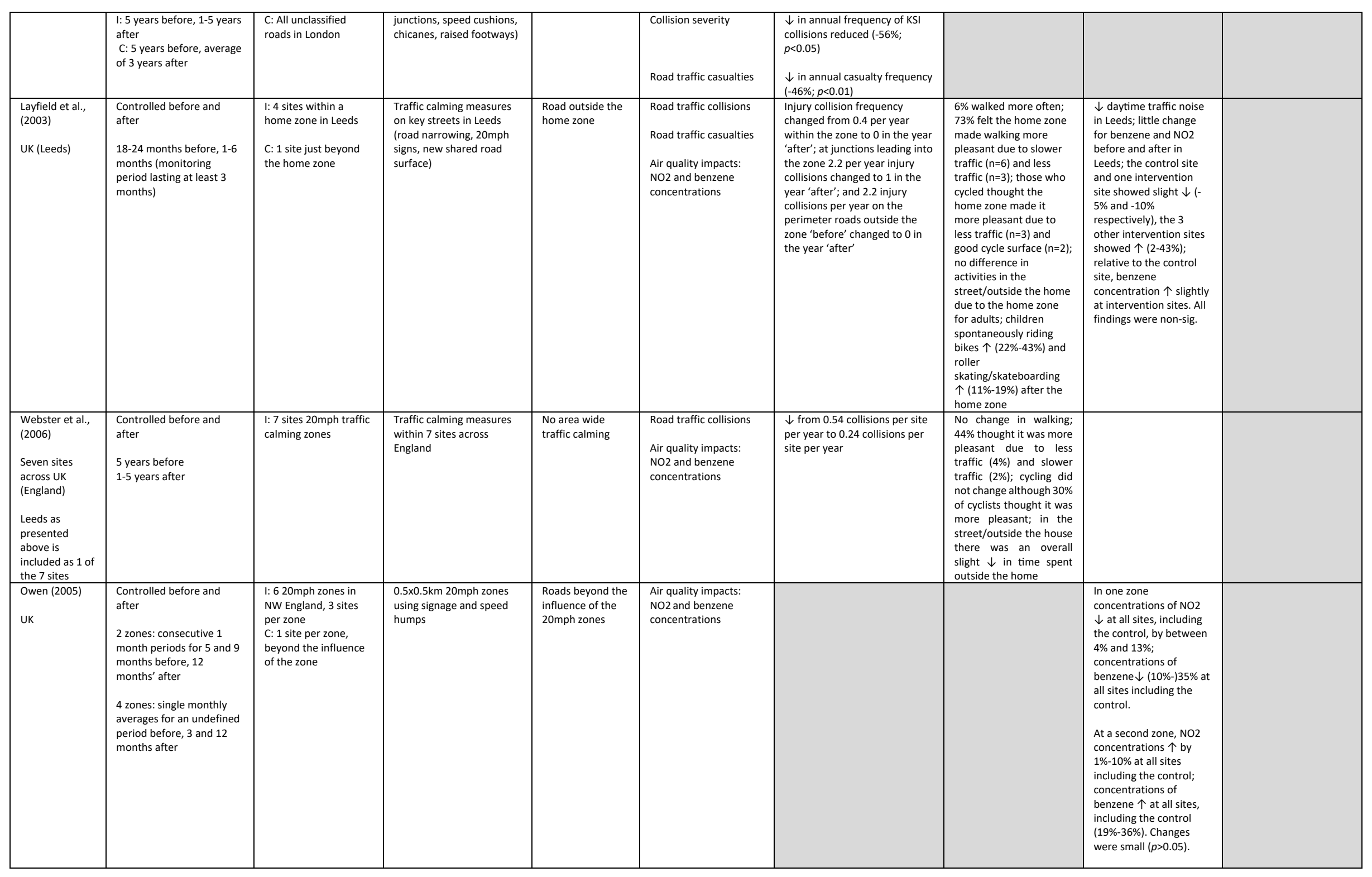




\begin{tabular}{|c|c|c|c|c|c|c|}
\hline $\begin{array}{l}\text { Steinbach et } \\
\text { al., (2011) } \\
\text { UK (London) }\end{array}$ & $\begin{array}{l}\text { Controlled interrupted } \\
\text { time series } \\
\text { Known implementation } \\
\text { date for each zone; roads } \\
\text { classified for each financial } \\
\text { year as pre-intervention, } \\
\text { under construction and } \\
\text { post implementation } \\
\text { Before and after periods } \\
\text { varied, with a maximum } \\
\text { after period of } 15 \text { years }\end{array}$ & $\begin{array}{l}\text { I: Roads in } 20 \mathrm{mph} \\
\text { zone in London, or } \\
\text { would become part of } \\
\text { one } \\
\text { C: Areas adjacent to } \\
20 \mathrm{mph} \text { zones, and all } \\
\text { other roads in London }\end{array}$ & $\begin{array}{l}\text { 20mph zones } \\
\text { Zones marked with } \\
\text { terminal signs (start and } \\
\text { end of the zone), with } \\
\text { traffic calming measures } \\
\text { at regular intervals } \\
\text { throughout } \\
\\
\text { The design of each zone } \\
\text { varied depending on the } \\
\text { local environment }\end{array}$ & No $20 \mathrm{mph}$ zones & $\begin{array}{l}\text { Inequalities: The effect } \\
\text { of } 20 \text { mph zones on } \\
\text { road casualties across } \\
\text { socioeconomic levels }\end{array}$ & $\begin{array}{l}\text { Similar effect across all } \\
\text { quintiles of } \\
\text { socioeconomic } \\
\text { deprivation; } 38.3 \%(95 \% \\
\text { Cl 31.5\% to } 45.0 \%) \downarrow \text { in } \\
\text { all casualties in the most } \\
\text { deprived quintilie (Q.5) } \\
\text { and a } 41.8 \%(21.0 \% \text { to } \\
62.6 \%) \downarrow \text { in the least } \\
\text { deprivived quintile (Q1) } \\
\text { (p=0.62 for trend across } \\
\text { deprivation quintiles) } \\
\text { Trend \% } \downarrow \text { in all } \\
\text { casualties on all roads, } \\
\text { was greater in the least } \\
\text { deprived areas } \\
\text { compared with the most } \\
\text { deprived areas (p<0.001) } \\
\text { Prevented more } \\
\text { casualties per } \mathrm{km} \text { of } \\
\text { road in most deprived } \\
\text { areas compared with } \\
\text { least deprived areas } \\
\text { (0.22/km in Q1 } \\
\text { compared with } 0.01 / \mathrm{km} \\
\text { in Q5) }\end{array}$ \\
\hline
\end{tabular}


Table 2 - Characteristics and results of studies examining the effect of 20 mph 'limits'

\begin{tabular}{|c|c|c|c|c|c|c|c|c|c|}
\hline \multirow[t]{2}{*}{$\begin{array}{l}\text { Study } \\
\end{array}$} & \multirow[t]{2}{*}{ Study Design } & \multirow[t]{2}{*}{ Participants } & \multirow[t]{2}{*}{ Intervention } & \multirow[t]{2}{*}{ Control } & \multirow[t]{2}{*}{$\begin{array}{l}\text { Outcome(s) } \\
\end{array}$} & \multicolumn{4}{|c|}{ Results } \\
\hline & & & & & & Collisions and casualties & Liveability & $\begin{array}{l}\text { Pollution } \\
\end{array}$ & $\begin{array}{l}\text { Inequalities } \\
\end{array}$ \\
\hline $\begin{array}{l}\text { Gaca et al., } \\
\text { (2016) } \\
\text { Poland }\end{array}$ & $\begin{array}{l}\text { Controlled before and } \\
\text { after } \\
\text { At least } 1 \text { year before and } \\
1 \text { year after }\end{array}$ & $\begin{array}{l}\text { I: } 10 \text { Tempo } 20 \\
\text { residential area } \\
\text { locations, } 35 \text { Tempo } \\
30 \text { speed limit } \\
\text { locations }\end{array}$ & $\begin{array}{l}\text { Tempo } 20 \text { and Tempo } 30 \\
\text { zones }\end{array}$ & $\begin{array}{l}\text { Untreated area in } \\
\text { region under } \\
\text { analysis }\end{array}$ & $\begin{array}{l}\text { Road Traffic collisions } \\
\text { Road Traffic causalities }\end{array}$ & $\begin{array}{l}\text { Tempo } 20 \text { and Tempo } 30 \text { zones } \\
\text { associated with } \downarrow \text { in KSI } \\
\text { casualties (average rate of } \\
27 \% \text { ); no positive effects for } \\
\text { collision reduction }\end{array}$ & & & \\
\hline $\begin{array}{l}\text { Atkins et al., } \\
(2018) \\
\text { UK } \\
12 \text { schemes }\end{array}$ & $\begin{array}{l}1220 \mathrm{mph} \text { case study } \\
\text { schemes in England with } \\
\text { comparator areas with a } \\
30 \mathrm{mph} \text { speed limit }\end{array}$ & $\begin{array}{l}\text { I: } 12 \text { schemes in } \\
\text { England: Walsall } \\
\text { (Rushall), Winchester } \\
\text { (Stanmorel, Liverpool } \\
\text { (Area 7), Liverpool } \\
\text { (Area 2), } \\
\text { Middleborough, } \\
\text { Calderdale (Phase 1) } \\
\text { Nottingham } \\
\text { (Bestwood), Brighton } \\
\text { (Phase 2), Portsmouth } \\
\text { Chichester, Brighton } \\
\text { (Phase 1), Winchester } \\
\text { (City centre) } \\
\text { C: Three comparator } \\
\text { areas are used to } \\
\text { identify background } \\
\text { trends in speeds on } \\
\text { 30mph roads with } \\
\text { similar characteristics } \\
\text { to the 'core schemes'; } \\
\text { and regional-based } \\
\text { data is used to identify } \\
\text { background trends in } \\
\text { collisions and } \\
\text { casualties on similar } \\
\text { 30mph roads. }\end{array}$ & $\begin{array}{l}12 \text { schemes lowered } \\
\text { speed limit from } 30 \mathrm{mph} \\
\text { to } 20 \text { mph through signage } \\
\text { and road markings, } \\
\text { supporting community } \\
\text { engagement activities to } \\
\text { raise awareness and } \\
\text { encourage support (none } \\
\text { involved the introduction } \\
\text { of physical traffic calming } \\
\text { measures or changes to } \\
\text { the street design) }\end{array}$ & $\begin{array}{l}3 \text { comparator } \\
\text { area used to } \\
\text { identify } \\
\text { background } \\
\text { trends in speeds } \\
\text { on 20mph roads } \\
\text { with similar } \\
\text { characteristics to } \\
\text { the 'core } \\
\text { schemes' and } \\
\text { regional-based } \\
\text { data used to } \\
\text { identify } \\
\text { background } \\
\text { trends in } \\
\text { collisions and } \\
\text { casualties on } \\
\text { similar } 30 \mathrm{mph} \\
\text { roads }\end{array}$ & $\begin{array}{l}\text { Road Traffic collisions } \\
\text { Road Traffic casualties } \\
\text { Perceptions of walking } \\
\text { and cycling } \\
\text { Mode of transport } \\
\text { Impacts on community, } \\
\text { local economy, } \\
\text { environment and } \\
\text { health }\end{array}$ & $\begin{array}{l}\text { Insufficient evidence to to } \\
\text { conclude a sig change in } \\
\text { collisions and casualties } \\
\text { following the introduction of } \\
20 m p h \text { limits in residential } \\
\text { areas, in the short term } \\
\text { For city centre the comparator } \\
\text { analysis shows that Brighton } \\
\text { Phase } 1 \text { is the only case study } \\
\text { area where the change in } \\
\text { collisions and casualties, } \\
\text { relative to the 30mph } \\
\text { comparator area was sig } \\
\text { (p<0.001). } \\
\text { Overall, no sig change in the } \\
\text { short term in collisions and } \\
\text { casualties, in the majority of the } \\
\text { case studies }\end{array}$ & 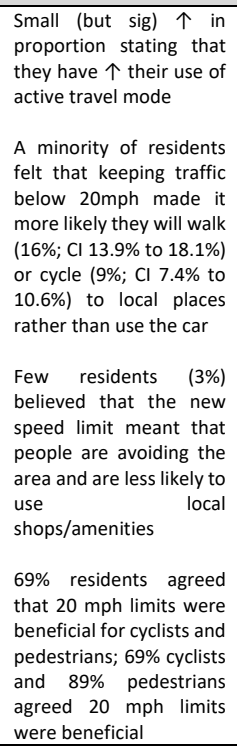 & $\begin{array}{l}\text { No primary data on air } \\
\text { quality, greenhouse gas } \\
\text { emissions, noise levels } \\
\text { was collected }\end{array}$ & \\
\hline
\end{tabular}


Table 3 - Quality appraisal and risk of bias in included studies

\begin{tabular}{|c|c|c|c|c|c|}
\hline Reference & Study design & Duration & Control & $\begin{array}{l}\text { Data source } \\
\end{array}$ & Other \\
\hline $\begin{array}{l}\text { Atkins et al., } \\
\text { (2018) } \\
\text { UK (England) }\end{array}$ & $\begin{array}{l}1220 \mathrm{mph} \text { case study } \\
\text { schemes in England } \\
\text { and various } \\
\text { comparator areas with } \\
\text { a } 30 \mathrm{mph} \text { limit }\end{array}$ & $\begin{array}{l}\text { Varied in each of the schemes. } 11 \\
\text { schemes implemented March } \\
\text { 2012-June } 2015 \text { and } 12^{2 \text { th }} \text { scheme } \\
\text { implemented before } 2010\end{array}$ & $\begin{array}{l}\text { Comparator sites with } 30 \mathrm{mph} \text { speed limit; } 3 \text { comparator } \\
\text { areas used to identify background trends in speeds on } \\
30 \mathrm{mph} \text { roads with similar characteristics to the 'core } \\
\text { schemes'; regional-based data used to identify background } \\
\text { trends in collisions and casualties on similar } 30 \mathrm{mph} \text { roads }\end{array}$ & $\begin{array}{l}\text { Questionnaires with } 2170 \text { residents living in or near the } 20 \mathrm{mph} \\
\text { limits, } 1256 \text { drivers living outside the case study areas and } 1655 \\
\text { cyclists and } 352 \text { motorcyclists nationwide. Interviews (177 non- } \\
\text { residents), } 9 \text { focus groups, stakeholder interviewers, analysis of } \\
\text { speed outcomes based on GPS vehicle data, spot speed data and } \\
\text { analysis of safety outcomes based on DfT road accident statistics } \\
\text { (STATS19) }\end{array}$ & Time frame of each case study scheme unclear \\
\hline $\begin{array}{l}\text { Brilon and } \\
\text { Blanke (1990; } \\
\text { 1993) } \\
\text { Germany }\end{array}$ & $\begin{array}{l}\text { Controlled before and } \\
\text { after }\end{array}$ & $\begin{array}{l}\text { Varied in each of the towns } \\
1-3 \text { years before, 1-3 years after }\end{array}$ & $\begin{array}{l}\text { Towns/areas similar in structure and traffic density, but } \\
\text { where no traffic calming measures were implemented } \\
\text { Each intervention town had } 1 \text { control area }\end{array}$ & Collision data obtained from police records & $\begin{array}{l}\text { Unclear which towns included a } 30 \mathrm{~km} / \mathrm{h} \text { speed limit; } \\
\text { intervention areas considered as a whole, although only } \\
\text { parts included a } 30 \mathrm{~km} / \mathrm{h} \text { zone; additional analyses limited } \\
\text { to traffic calmed streets within intervention area, but again } \\
\text { only some of these streets included a } 30 \mathrm{~km} / \mathrm{h} \text { zone; specific } \\
\text { effect of } 30 \mathrm{~km} / \mathrm{zones} \text { not distinguished in the results }\end{array}$ \\
\hline $\begin{array}{l}\text { Engel and } \\
\text { Thomsen } \\
\text { (1992) } \\
\text { Denmark }\end{array}$ & $\begin{array}{l}\text { Controlled before and } \\
\text { after }\end{array}$ & 3 years before, 3 years after & $\begin{array}{l}\text { All urban streets in Denmark that belong to local } \\
\text { government authorities (18,935km of streets) }\end{array}$ & Collision and causality data obtained from police records & \\
\hline $\begin{array}{l}\text { Gaca et al., } \\
\text { (2016) } \\
\text { Poland } \\
\end{array}$ & $\begin{array}{l}\text { Controlled before and } \\
\text { after }\end{array}$ & $\begin{array}{l}\text { At least } 1 \text { year before and } 1 \text { year } \\
\text { after }\end{array}$ & Untreated areas in region under analysis & Collision and causality data obtained from police records & $\begin{array}{l}\text { Study included } 5,15 \mathrm{~km} / \mathrm{h} \text { streets alongside } 39,30 \mathrm{~km} / \mathrm{h} \\
\text { streets; effect of each not distinguished in the results }\end{array}$ \\
\hline $\begin{array}{l}\text { Grundy et al., } \\
\text { (2009) } \\
\text { UK (London) }\end{array}$ & $\begin{array}{l}\text { Controlled interrupted } \\
\text { time series }\end{array}$ & $\begin{array}{l}\text { Before and after time periods } \\
\text { unclear. Varied for each road, } \\
\text { maximum after period was } 15 \\
\text { years }\end{array}$ & $\begin{array}{l}\text { All areas adjacent to } 20 \mathrm{mph} \text { zones and all other roads in } \\
\text { London }\end{array}$ & $\begin{array}{l}\text { Police STATS19 data, linked to road segment data through a GIS. } \\
\text { Using the } 2004 \text { index of multiple deprivation for the lower super } \\
\text { output area (LSOA), road segments categorised by deprivation } \\
\text { quintile }\end{array}$ & $\begin{array}{l}\text { Unable to account for possible impact of other road safety } \\
\text { initiatives. However, it was possible that this confounding } \\
\text { would affect both intervention and control roads }\end{array}$ \\
\hline $\begin{array}{l}\text { Layfield et al., } \\
\text { (2003) } \\
\text { UK (Leeds) }\end{array}$ & $\begin{array}{l}\text { Controlled before and } \\
\text { after }\end{array}$ & $\begin{array}{l}\text { 18-24 months before, 1-6 months } \\
\text { after with each monitoring } \\
\text { periods lasting at least } 3 \text { months }\end{array}$ & 1 site, just beyond influence of zone & $\begin{array}{l}\text { Interview surveys (children and adults), automatic traffic } \\
\text { counters and tube detectors, police STATS19 data and noise and } \\
\text { air quality measures (Leeds only) }\end{array}$ & $\begin{array}{l}\text { Before and after periods undertaken at the same time of } \\
\text { year to minimise seasonal effects }\end{array}$ \\
\hline $\begin{array}{l}\text { Li and Graham } \\
\text { (2016) } \\
\text { UK (London) }\end{array}$ & $\begin{array}{l}\text { Doubly robust } \\
\text { estimation } \\
\text { (combination of } \\
\text { outcome regression } \\
\text { and propensity score } \\
\text { models) }\end{array}$ & 3 years before, 3 years after & $\begin{array}{l}\text { As } 20 \text { mph zone may affect neighbouring areas, those within } \\
150 \mathrm{~m} \text { of each } 20 \text { mph zones were excluded as potential } \\
\text { controls. } 2844 \text { potential control zones were selected, refined } \\
\text { to } 1415 \text { with matching to improve the balance of } \\
\text { characteristics between intervention and control group. } \\
\text { Population density, green space and road traffic injuries at } \\
\text { baseline were included }\end{array}$ & $\begin{array}{l}\text { Collision data obtained from police records (STATS19). Locations } \\
\text { were recorded using the British National Grid coordinate system } \\
\text { and GIS software. The index of multiple deprivation (IMD) was } \\
\text { obtained from the office for the Deputy Prime Minister). Road } \\
\text { network information was obtained from Ordnance Survey (OS) } \\
\text { Meridian }\end{array}$ & $\begin{array}{l}\text { Associations between casualties and road network } \\
\text { characteristics addressed via a detailed panel data set on } \\
\text { road network design }\end{array}$ \\
\hline $\begin{array}{l}\text { Owen (2005) } \\
\text { UK }\end{array}$ & $\begin{array}{l}\text { Controlled before and } \\
\text { after }\end{array}$ & $\begin{array}{l}2 \text { zones: consecutive } 1 \text { month } \\
\text { periods for } 5 \text { and } 9 \text { months } \\
\text { before, } 12 \text { months' after. } 4 \text { zones: } \\
\text { single monthly averages for an } \\
\text { undefined period before, } 3 \text { and } 12 \\
\text { months after }\end{array}$ & $\begin{array}{l}6 \text { control roads ( } 1 \text { per zone) beyond the influence of the } 20 \\
\text { mph zone. }\end{array}$ & Diffusion tubes (NO2) and thermal desorption tubes (benzene) & Seasonal average was calculated for comparison \\
\hline $\begin{array}{l}\text { Steinbach et } \\
\text { al., (2011) } \\
\text { UK (London) }\end{array}$ & $\begin{array}{l}\text { Controlled interrupted } \\
\text { time series }\end{array}$ & $\begin{array}{l}\text { Before and after time periods } \\
\text { unclear. Varied for each road, } \\
\text { maximum after period is } 15 \text { years }\end{array}$ & $\begin{array}{l}\text { All areas adjacent to } 20 \mathrm{mph} \text { zones and all other roads in } \\
\text { London }\end{array}$ & $\begin{array}{l}\text { Police STATS19 data, linked to road segment data through a GIS. } \\
\text { Using the } 2004 \text { index of multiple deprivation for the lower super } \\
\text { output area (LSOA), road segments were categorised by } \\
\text { deprivation quintile }\end{array}$ & $\begin{array}{l}\text { Unable to account for possible impact of other road safety } \\
\text { initiatives. However, possible that this confounding would } \\
\text { affect both intervention and control roads }\end{array}$ \\
\hline $\begin{array}{l}\text { Vis et al., } \\
\text { (1992) } \\
\text { Netherlands }\end{array}$ & $\begin{array}{l}\text { Controlled before and } \\
\text { after }\end{array}$ & $\begin{array}{l}\text { Before and after periods not } \\
\text { provided }\end{array}$ & $\begin{array}{l}\text { Built up areas of the municipalities in which the zones were } \\
\text { located (excluding arterial roads) }\end{array}$ & Not stated & $\begin{array}{l}\text { Observations not always made at similar times, traffic } \\
\text { situations and weather conditions before and after } \\
\text { implementation }\end{array}$ \\
\hline $\begin{array}{l}\text { Webster and } \\
\text { Layfield } \\
\text { (2007) } \\
\text { UK (London) }\end{array}$ & $\begin{array}{l}\text { Controlled before and } \\
\text { after }\end{array}$ & $\begin{array}{l}\text { 1: } 5 \text { years before, } 1-5 \text { years after } \\
\text { C: } 5 \text { years before, average of } 3 \\
\text { years after }\end{array}$ & All unclassified roads in London & $\begin{array}{l}\text { Data on location, installation date and measures use in each zone } \\
\text { was obtained from London Boroughs. Collision and casualty data } \\
\text { was obtained from the London Accident Analysis Unit (LAAU). }\end{array}$ & \\
\hline $\begin{array}{l}\text { Webster et al., } \\
\text { (2006) } \\
7 \text { sites across } \\
\text { England }\end{array}$ & $\begin{array}{l}\text { Controlled before and } \\
\text { after }\end{array}$ & $\begin{array}{l}\text { 18-24 months before, } 1-6 \text { months } \\
\text { after with each monitoring period } \\
\text { lasting at least } 3 \text { months }\end{array}$ & Sites just beyond influence of zone & $\begin{array}{l}\text { Interview surveys (children and adults), automatic traffic } \\
\text { counters and tube detectors, police STATS19 data and noise and } \\
\text { air quality measures (Leeds only) }\end{array}$ & $\begin{array}{l}\text { Before and after periods undertaken at the same time of } \\
\text { year to minimise seasonal effects }\end{array}$ \\
\hline
\end{tabular}


